\title{
Critical success factors for technology-based startups
}

\section{José Santisteban and David Mauricio*}

\author{
Department of Computer Science, \\ Universidad Nacional Mayor de San Marcos, \\ Calle Germán Amézaga 375, Ciudad Universitaria, Lima 01, Peru \\ Email: jsantistebanp1@unmsm.edu.pe \\ Email:dmauricios@unmsm.edu.pe \\ *Corresponding author
}

\section{Orestes Cachay}

\author{
Faculty of Industrial Engineering, \\ Universidad Nacional Mayor de San Marcos, \\ Calle Germán Amézaga 375, Ciudad Universitaria, Lima 01, Peru \\ Email: ocachayb@unmsm.edu.pe
}

\begin{abstract}
Technology-based startups (TBSs) significantly contribute to the generation of jobs and economic development; therefore, the success of these companies should be guaranteed. However, despite their importance, TBSs have a high failure rate worldwide. The objective of this study is to identify CSFs for TBSs based on the analysis of the information systems theory, as well as theories on human, social, and organisational behaviour. This descriptive empirical study performed a simple correspondence analysis of the perceptions of 125 CEOs of TBSs located in Peru using student's t-test. The following effects were identified: technological surveillance $\rightarrow$ knowledge absorptive capacity, knowledge absorptive capacity $\rightarrow$ perceived performance of a product and/or service, knowledge absorptive capacity $\rightarrow$ dynamic capability, knowledge absorptive capacity $\rightarrow$ innovative and entrepreneurial culture, the perceived performance of a product and/or service $\rightarrow$ customer satisfaction, and the quality of a product and/or service $\rightarrow$ customer satisfaction. The results of the simple correspondence analysis showed that all identified relationships were valid using student's t-test at a $95 \%$ confidence level, with a high or very high effect, except for the impact of knowledge absorptive capacity on the innovative and entrepreneurial culture. This study identified ten CSFs for TBSs.
\end{abstract}

Keywords: technology-based startup; TBS; critical success factors; CSFs; IT startup; new technology-based firm; entrepreneurship.

Reference to this paper should be made as follows: Santisteban, J., Mauricio, D. and Cachay, O. (2021) 'Critical success factors for technology-based startups', Int. J. Entrepreneurship and Small Business, Vol. 42, No. 4, pp.397-421.

Biographical notes: José Santisteban is a System Engineer, received his Magister in Systems Engineering and currently a Doctoral candidate at the Faculty of System Engineering and Informatics, Universidad Nacional Mayor 
de San Marcos, Peru. He has more than ten years of experience in implementing information systems in different business sectors. His main research areas are the study of artificial intelligence and technological entrepreneurship.

David Mauricio is a Doctor of Science in Systems Engineering and Computer Science and Master of Science in Applied Mathematics by the Federal University of Rio de Janeiro, Brazil. He had taught at the State University of North Fluminense Brazil in 1994 to 1998. He is a Professor at the Universidad Nacional Mayor de San Marcos since 1998. His areas of interest are mathematical programming, artificial intelligence, software engineering and entrepreneurship.

Orestes Cachay is the Rector of the Universidad Nacional Mayor de San Marcos. He has the academic degree of Doctor of Industrial Engineering, degree conferred by the Universidad Nacional Mayor de San Marcos. He is an Industrial Engineer with knowledge for the optimal management of resources applied to the different organisational processes.

\section{Introduction}

Many readers associate Peru with its history and the Incas (Dana, 1988). The end of the 1980s Peru was submerged in economic crisis (Nishimura and Tristán, 2011). In the 1990s, as a result of a stable economy, companies formed by one person grow in Peru (Chaston and Scott, 2012). In addition, from the new century onwards, a large number of young people with a business vision emerged with the aim of creating new business initiatives. According to the Central Reserve Bank of Peru the $60 \%$ of production is done informally, $40 \%$ of the labour force work is self-employed in informal micro-enterprises (Dana and Mallet, 2014). According to the Global Entrpreneurship Monitor Report (2017) Peru ranked first in the entrepreneurial spirit index in Latin America (Serida et al., 2017), and in 2019 Peru was the fifth country with the most entrepreneurs worldwide.

In many countries, there are increasing number of innovative businesses being created, in particular new technology-based companies (startups) (Hormiga et al., 2010). Krejci et al. (2015) have shown that technology-based startups (TBSs) are new, including temporary companies whose business model is based on technology and innovation, and that these companies have a high potential for growth and scalability. TBSs have been recognised by governments worldwide for their contribution to economic stability and growth (Wei-Wen, 2009) and are considered the primary contributors to job creation (Sulayman et al., 2014) and technological innovation. Some leading technology companies, including Apple, Cisco, eBay, Qualcomm, and Intel, were startups reliant on external funding during their formative years (Spiegel et al., 2015).

The impact of TBSs on the global economy is significant (Van Gelderen et al., 2005). However, these companies have a high failure rate worldwide (Colombo and Grilli, 2005; McAdam and McAdam, 2008). Ejermo and Xiao (2014) reported that from 1990 to 2000, only $21 \%$ of TBSs in Sweden survived for more than five years, and Hyder and Lussier (2016) found that more than $80 \%$ of startups in Pakistan failed in the first year of operation. Furthermore, most startups are small with limited resources and compete with large and experienced companies (Schneider et al., 2007). 
Prohorovs et al. (2018) reported that TBSs have received a lot of attention in entrepreneurship literature in the last two decades. Reynolds and Miller (1992) were the first to study critical success factors (CSFs) for TBSs. This research has continued, including in 2017 when Santisteban and Mauricio described 21 elements that are critical for entrepreneurial success. However, the failure rate of these companies is high, suggesting the presence of other CSFs.

This study identified ten CSFs for TBSs: technological surveillance, knowledge absorptive capacity, the perceived performance of a product and/or service, the quality of a product and/or service, customer satisfaction, staged financing, the support of a business incubator, innovation and entrepreneurship ecosystem, the dynamic capability of the entrepreneurial team, and innovative and entrepreneurial culture. Five of these factors were supported by the theories of absorptive capacity, expectation confirmation, dynamic capability, and the success model of information systems proposed by Delone and McLean.

The impact of CSFs was assessed by analysing the perception of entrepreneurs from 125 TBSs. The results of the simple correspondence analysis (SCA) indicated that the effect of all factors was either high or very high. Through a graph that shows which factors are related to success, i.e., the closer two data points are to each other, the closer their relationship is to each other, and the stronger is their influence.

This article has seven sections. Section 2 investigates the literature on TBSs, the characteristics of business success, and known CSFs for businesses. Section 3 describes other CSFs for TBSs and 12 hypotheses. Section 4 addresses the research methodology used to corroborate the relevance of these factors and hypotheses. Sections 5 and 6 present the results and discussion, respectively, and Section 7 concludes.

\section{Literature review}

This section presents a literature review on CSFs for startups.

\subsection{Startup}

There are different definitions of a startup (Table 1), and there is no consensus on its definition. Because in the literature there are several studies that attempt to define a startup and it is concluded that there is no standard definition. However, there is agreement that startups are small and characterised by innovation, rapid growth, scalability, and high risk. Therefore:

"A startup is a small, dynamic, flexible, high-risk company that has a reproducible and scalable business model and provides innovative products and/or services."

In addition, TBSs were defined as companies that provide innovative IT-based products and/or services. 
Table 1 Definitions of startup

\begin{tabular}{|c|c|}
\hline Source & Definitions \\
\hline $\begin{array}{l}\text { Kakati (2003), Spyros and } \\
\text { Nickolaos (2012) }\end{array}$ & $\begin{array}{l}\text { Temporary organisations that use advanced technology to create } \\
\text { innovative products and/or services. }\end{array}$ \\
\hline $\begin{array}{l}\text { Chorev and Anderson } \\
\text { (2006), Thiranagama and } \\
\text { Edirisinghe (2015) }\end{array}$ & Organisations at an early stage of development. \\
\hline Gimmon and Levie (2010) & $\begin{array}{l}\text { Dynamic and flexible companies that evolve along with the } \\
\text { market. }\end{array}$ \\
\hline $\begin{array}{l}\text { Ries (2011), } \\
\text { Chen et al. (2019) }\end{array}$ & $\begin{array}{l}\text { Organisations that create new products and/or services in an } \\
\text { environment of high uncertainty. }\end{array}$ \\
\hline Blank and Dorf (2012) & $\begin{array}{l}\text { Temporary organisations with a reproducible and scalable business } \\
\text { model. }\end{array}$ \\
\hline $\begin{array}{l}\text { Festel et al. (2013), } \\
\text { Sefiani and Bown (2013) }\end{array}$ & $\begin{array}{l}\text { Technology-based small and medium companies with a high } \\
\text { likelihood of success and that tend to lack the financial resources } \\
\text { necessary to create a robust business model because of the } \\
\text { company's limited experience and the small number of employees, } \\
\text { requiring external funding to sustain growth. }\end{array}$ \\
\hline CAF (2015) & $\begin{array}{l}\text { Business initiatives operated by entrepreneurial teams that identify } \\
\text { a business opportunity with high growth potential on a regional or } \\
\text { global scale. }\end{array}$ \\
\hline Hale (2019) & Company that is designed or created to try to grow very quickly. \\
\hline $\begin{array}{l}\text { Krejci et al. (2015), } \\
\text { Prohorovs et al. (2018) }\end{array}$ & $\begin{array}{l}\text { Emerging and temporary companies with potential for rapid } \\
\text { growth and scalability and whose business model is based on } \\
\text { innovation and technology. }\end{array}$ \\
\hline OECD (2016) & $\begin{array}{l}\text { Innovative companies that provide solutions to emerging problems } \\
\text { or create new demands by developing new business models. }\end{array}$ \\
\hline $\begin{array}{l}\text { World Economic Forum } \\
\text { (2018) }\end{array}$ & Emerging and intrinsically innovative technology companies. \\
\hline Petru et al. (2019) & $\begin{array}{l}\text { Scalable companies with low incremental costs and potential for } \\
\text { significant growth in the short-term. }\end{array}$ \\
\hline $\begin{array}{l}\text { Garcia-Muiña and } \\
\text { Navas-López (2007), } \\
\text { Konsek-Ciechonska (2019) }\end{array}$ & $\begin{array}{l}\text { Organisations that create new products or services in conditions of } \\
\text { high uncertainty and search for business models that, once tested, } \\
\text { can promote business growth }\end{array}$ \\
\hline
\end{tabular}

\subsection{Business success}

There are different definitions of what success is for startups, and no consensus exists in the literature (Table 2). For instance, entrepreneurs define success as the ability to generate new jobs and achieve personal fulfilment, whereas investors define success as the ability to make profit (Roa et al., 2018; Kim et al., 2018; Cabrera and Mauricio, 2017). 
Table 2 Definitions of the success of startups

\begin{tabular}{|c|c|c|}
\hline$I D$ & Definition & Source \\
\hline D1 & $\begin{array}{l}\text { Achieve the company's goals and } \\
\text { objectives and have effective } \\
\text { management. }\end{array}$ & $\begin{array}{l}\text { Davidsson et al. (1994), Anh et al. (2012), } \\
\text { Yoon-Jun (2010), Yoo et al. (2012), Hyder and } \\
\text { Lussier (2016) }\end{array}$ \\
\hline D2 & High financial performance. & $\begin{array}{l}\text { Morteza et al. (2013), Dornberger and Zeng } \\
(2009) \text {, Preisendorfer et al. (2012), Spiegel et al. } \\
\text { (2015) }\end{array}$ \\
\hline D3 & $\begin{array}{l}\text { Increase in sales and profits, and the } \\
\text { increase have to be similar to or } \\
\text { higher than the industry average. }\end{array}$ & $\begin{array}{l}\text { Oakey (2003), Hormiga et al. (2010), Strehle } \\
\text { et al. (2010) }\end{array}$ \\
\hline D4 & $\begin{array}{l}\text { Businesses that allow free time and } \\
\text { promote well-being. }\end{array}$ & $\begin{array}{l}\text { Oakey (2003), Chirjevskis and Dvortsova } \\
\text { (2012), Balboni et al. (2014) }\end{array}$ \\
\hline D5 & $\begin{array}{l}\text { Success is defined by the number of } \\
\text { jobs that the company has generated. }\end{array}$ & Maine et al. (2010), Banda and Lussier (2015) \\
\hline D6 & Market share and number of clients. & $\begin{array}{l}\text { Van Gelderen et al. (2005), Kim and Heshmati } \\
\text { (2010) }\end{array}$ \\
\hline D7 & $\begin{array}{l}\text { Being purchased by another company } \\
\text { or being listed on the stock market. }\end{array}$ & $\begin{array}{l}\text { Colombo and Grilli (2010), Krejci et al. (2015), } \\
\text { Hyder and Lussier (2016) }\end{array}$ \\
\hline D8 & $\begin{array}{l}\text { Meet the demands of employees and } \\
\text { customers. }\end{array}$ & Strehle et al. (2010), Pirolo and Presutti (2010) \\
\hline D9 & $\begin{array}{l}\text { Develop high-quality products and/or } \\
\text { services that help satisfy unmet needs } \\
\text { and improve people's lives. }\end{array}$ & $\begin{array}{l}\text { Hyder and Lussier (2016), Sulayman et al. } \\
\text { (2014), Kim and Heshmati (2010), Yoo et al. } \\
\text { (2012) }\end{array}$ \\
\hline
\end{tabular}

The conditions for achieving success are limited. For instance, the increase in sales cannot be determined if a TBS makes a single purchase of a product and/or service or the company is for sale. Job positions do not apply to IT companies that can operate with a few workers because processes and services are fully automated. Market participation does not apply to TBSs whose clients are large companies that use their services permanently, such as fintechs, which are acquired by large banks. However, success involves making profits, selling products and/or services, meeting the demands of customers, selling the company, or being listed on the stock market. Therefore:

"Successful startups meet the demands of customers and organisations, have higher profits than other companies in the same industrial sector, are acquired by another company for a price higher than its value, and have a stock market value higher than its base value."

The proposed definitions of TBS satisfies those shown in Table 2, except for D5 and D6, because the possibility of being sold to a large company or having a stock market value higher than its base value satisfies D1 and D7, having profits higher than the industry average satisfies D2 and D3, meeting the demands of employees through business success satisfies D8, and meeting the demands of customers satisfies D4 and D9.

\subsection{Identification of critical factors of success}

In the present study, CSFs were considered elements that affected the success of startups (Abou-Moghli and Al-Kasasbeh, 2012). A large number of studies identified CSFs for TBSs A total of 1.013 potential studies were identified, and 21 factors were identified in 
the state-of-the-art study by Santisteban and Mauricio (2017), who analysed 74 articles on this topic (Table A1). Positive and negative factors are shown as + and -, respectively.

\section{New critical factors identified}

This section details and supports new CSFs that positively influence the success of the TBSs.

\section{$3.1 \mathrm{CSFS}$}

Seventy-seven theories related to information systems, as well as theories on human, social, and organisational behaviour, have been reviewed in relation to business success. The following CSFs were identified on the basis of these theories and other data sources:

- Technological surveillance (F1) is the systematic identification, analysis, dissemination, and exploration of technical information used for business survival and growth (Ko and An, 2019). Roa et al. (2018) have shown that technological surveillance allows innovative organisations to obtain information on other products and/or services or emerging technologies, thereby achieving sustainable success.

- Knowledge absorptive capacity (F2) is the ability of the business team to recognise, assimilate, and apply external knowledge to the organisation to add value to customers (Senivongse et al., 2019).

- $\quad$ Perceived performance (F3) is high performance in delivering a high-value product and/or service to the customer (Arefin et al., 2019). A high level of performance in meeting customer's expectations creates brand loyalty and promotes business growth.

- Quality (F4) is the set of inherent characteristics or properties of products and/or services, which meet the needs of customers and allow a company to achieve business success (Al-Fraihat et al., 2020).

- Customer satisfaction (F5) is currently the primary goal of small, medium, large, national, and internal companies (Bocken, 2015). It is key to business sustainability and growth (Luna-Perejon et al., 2019). However, companies vary in how successful they are in maintaining customer satisfaction, which looks different for each company.

- Staged financing (F6) is the set of financing instruments provided by different actors of the entrepreneurship and innovation ecosystem (local governments, angel investors, and private companies, among others) to assist companies in achieving sustainable growth and success during each stage of the TBS life cycle (Honorine and Emmanuelle, 2019).

- The support for a business incubator (F7) creates environments and conditions that facilitate the formation and success of new startups (Murray, 2019). The main benefits of business incubators are their ability to expedite the launch of innovative products and/or services in the market, provide access to risk capital and funding 
agencies, as well as the advice, mentoring, and support of business experts during the first years of operation.

- The innovation and entrepreneurship ecosystem (F8) is the relationship between public and private entities and entrepreneurs, which facilitate the success of emerging technology-based companies (Corrales-Estrada, 2019). This ecosystem offers many advantages to innovative companies, including access to funding sources, trained personnel, and business networks.

- Dynamic capability (F9) is the ability of organisations to integrate and build internal and external competencies to quickly address changing market conditions (Arora et al., 2019) and systematically solve problems. Therefore, dynamic capability is a source of competitive advantage and business success (Arora et al., 2019).

- Innovative and entrepreneurial culture (F10) is the ability to identify opportunities and obtain resources that can transform opportunities into successful ventures (Roy et al., 2020). Corrales-Estrada (2019) shows that the culture of pioneering organisations includes aspects related to the workforce and working environment. The two elements necessary for the success of an organisation are creative employees and culture of innovation (Corrales-Estrada, 2019). The growth and success of companies depend on the talent pool and the ability to develop an innovative business culture in line with local demands.

The identified CSFs and definitions are summarised in Table 3.

\subsection{Hypothesis}

The relationships between CSFs and TBSs success were established and 12 hypotheses were formulated to meet the research objective (Figure 1).

Figure 1 Initial conceptual model

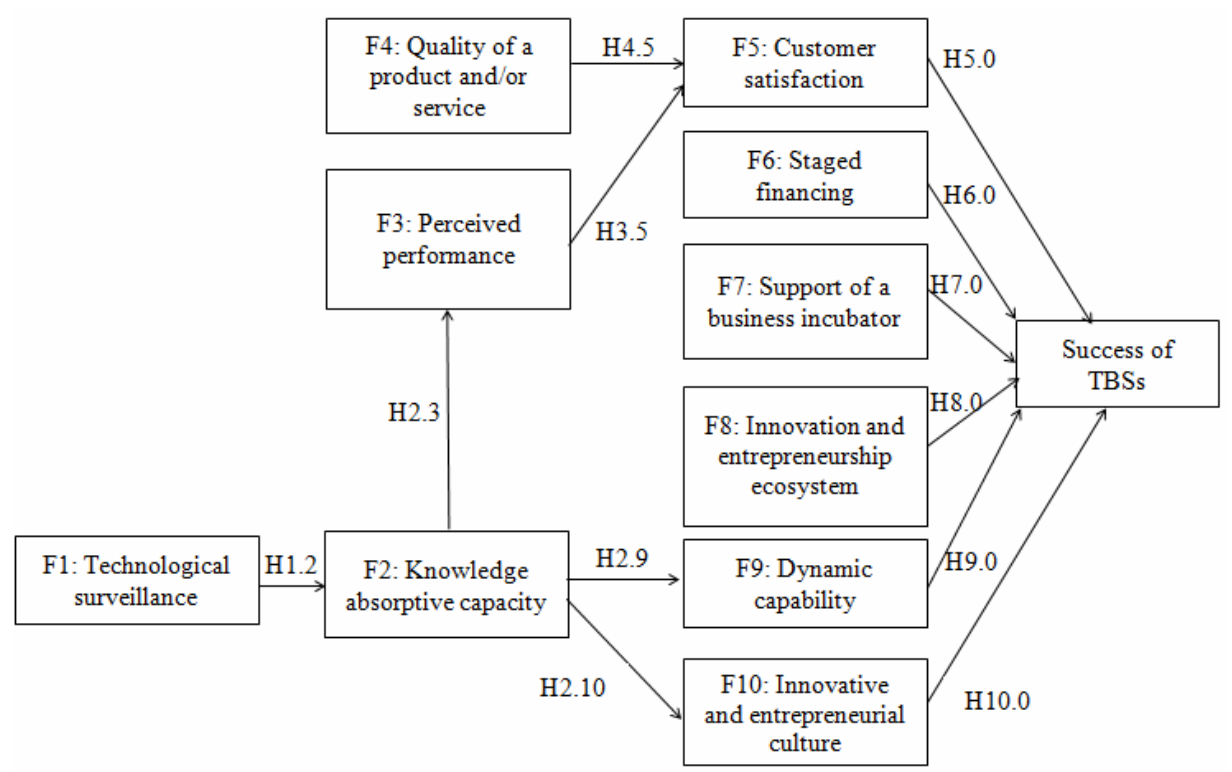


Table 3 New factors influencing the success of TBS

\begin{tabular}{|c|c|c|c|}
\hline$I D$ & Factor & Definition & Justification \\
\hline F1 & $\begin{array}{l}\text { Technological } \\
\text { surveillance }\end{array}$ & $\begin{array}{l}\text { An organised and permanent way of } \\
\text { obtaining external information on } \\
\text { science and technology, analysing it, } \\
\text { and turning it into knowledge for } \\
\text { decision-making. }\end{array}$ & $\begin{array}{l}\text { Ko and An (2019), } \\
\text { Roa et al. (2018) }\end{array}$ \\
\hline $\mathrm{F} 2$ & $\begin{array}{l}\text { Knowledge } \\
\text { absorptive capacity }\end{array}$ & $\begin{array}{l}\text { The ability of the entrepreneurial team } \\
\text { to identify, assimilate, transform, and } \\
\text { exploit knowledge. }\end{array}$ & $\begin{array}{l}\text { Absorptive capacity theory } \\
\text { (Senivongse et al., 2019) }\end{array}$ \\
\hline F3 & $\begin{array}{l}\text { Perceived } \\
\text { performance }\end{array}$ & $\begin{array}{l}\text { The high performance of a product } \\
\text { and/or service acquired by customers. }\end{array}$ & $\begin{array}{l}\text { Expectation confirmation } \\
\text { theory (Arefin et al., 2019) }\end{array}$ \\
\hline F4 & $\begin{array}{l}\text { Quality of a } \\
\text { product and/or } \\
\text { service }\end{array}$ & $\begin{array}{l}\text { The characteristics of a product or } \\
\text { service that satisfy the needs of } \\
\text { customers. }\end{array}$ & $\begin{array}{l}\text { Delone and McLean IS } \\
\text { success model (Al-Fraihat } \\
\text { et al., 2020) }\end{array}$ \\
\hline F5 & $\begin{array}{l}\text { Customer } \\
\text { satisfaction }\end{array}$ & $\begin{array}{l}\text { Meeting or exceeding customer } \\
\text { expectations through a product and/or } \\
\text { service. }\end{array}$ & $\begin{array}{l}\text { Delone and McLean IS } \\
\text { success model } \\
\text { (Luna-Perejon et al., 2019) }\end{array}$ \\
\hline F6 & Staged financing & $\begin{array}{l}\text { The development of adequate } \\
\text { financing instruments throughout the } \\
\text { life cycle of TBSs. }\end{array}$ & $\begin{array}{l}\text { Honorine and Emmanuelle } \\
\text { (2019) }\end{array}$ \\
\hline F7 & $\begin{array}{l}\text { Support of a } \\
\text { business incubator }\end{array}$ & $\begin{array}{l}\text { Business incubators involved in } \\
\text { training, support, and sustainable } \\
\text { growth. }\end{array}$ & Murray (2019) \\
\hline F8 & $\begin{array}{l}\text { Innovation and } \\
\text { entrepreneurship } \\
\text { ecosystem }\end{array}$ & $\begin{array}{l}\text { The set of public and private } \\
\text { institutions and people that support } \\
\text { innovation and entrepreneurship. }\end{array}$ & Corrales-Estrada (2019) \\
\hline F9 & $\begin{array}{l}\text { Dynamic capability } \\
\text { of entrepreneurs }\end{array}$ & $\begin{array}{l}\text { The potential of the entrepreneurial } \\
\text { team to solve risk situations and/or } \\
\text { problems. }\end{array}$ & $\begin{array}{l}\text { Dynamic capabilities theory } \\
\text { (Arora et al., 2019) }\end{array}$ \\
\hline F10 & $\begin{array}{l}\text { Innovative and } \\
\text { entrepreneurial } \\
\text { culture }\end{array}$ & $\begin{array}{l}\text { Generating original ideas to improve } \\
\text { business success. }\end{array}$ & $\begin{array}{l}\text { Roy et al. (2020), } \\
\text { Corrales-Estrada (2019) }\end{array}$ \\
\hline
\end{tabular}

\subsubsection{Technological surveillance (F1)}

Technological surveillance is more relevant for organisations whose raison d'être is innovation, as is the case for TBSs. These companies should adopt an organised, selective, and permanent process of technological surveillance as a business model to identify scientific and/or technical innovations or new market threats. Therefore, the entrepreneurial team should exploit external knowledge (F2) to predict its potential market and create or improve products and/or services. Therefore, we conclude that:

Hypothesis H1.2 Technological surveillance improves knowledge absorption capacity.

\subsubsection{Knowledge absorption capacity (F2)}

Knowledge absorptive capacity directly and indirectly affects the value of a product and/or service, improves processes, increases production capacity, reduces costs, and 
improves technology and innovation, and consequently increases the value of a product and/or service. This added value benefits customers (F3). Therefore, we conclude that:

Hypothesis H2.3 Knowledge absorption capacity improves perceived performance.

Furthermore, the ability to absorb external knowledge allows organisations to develop new skills to cope with complex situations, increasing the chance of business survival and growth (Lasch et al., 2007). Sulayman et al. (2014) described dynamic capability as the potential of a company to generate new knowledge (F9) based on the continuous creation, improvement, and expansion of local knowledge. Therefore, we conclude that:

Hypothesis H2.9 Absorption capability improves dynamic capability.

Chirjevskis and Dvortsova (2012) have shown that knowledge absorptive capacity is a learning process oriented towards innovation. [Colombo et al. (2004) demonstrated that this capacity was converted to specific business strategies, and their strengthening sought to maximise intellectual assets and improve organisational culture (F10).] Therefore, we conclude that:

Hypothesis H2.10 Knowledge absorption capacity improves the innovative and entrepreneurial culture.

\subsubsection{Perceived performance (F3)}

The high value of a product and/or service improves customer satisfaction, stimulating repeated purchases and appreciation of the value of TBSs (F5), increasing the interest of other customers in purchasing the product and/or service, and ultimately increasing sales. Therefore, we conclude that:

Hypothesis H3.5 Perceived performance improves customer satisfaction.

\subsubsection{Quality of the product and/or service (F4)}

TBSs cannot achieve success without guaranteeing the high quality of products and/or services. Therefore, providing quality products and/or services is crucial to satisfy customer needs. Strehle et al. (2010) and Hormiga et al. (2011) have shown that customers appreciate products and/or services that are of high-quality and meet or exceed their expectations (F5). Therefore, we conclude that:

Hypothesis H4.5 The quality of a product and/or service improves customer satisfaction.

\subsubsection{Customer satisfaction (F5)}

The theory of Delone and McLean's IS success model postulates that the higher customer satisfaction, the greater the probability of acceptance of the organisation; in addition, the higher customer satisfaction, the greater the acceptance of the products and/or services provided by TBSs, i.e., product sales increase. Therefore, we conclude that:

Hypothesis H5.0 Customer satisfaction improves the success of TBSs. 


\subsubsection{Staged financing (F6)}

Funding organisations with innovative business models are fundamental for the long-term survival and growth of businesses (Honorine and Emmanuelle, 2019). Given that startups have innovative business models, we can affirm that:

Hypothesis H6.0 Staged financing improves the success of TBSs.

\subsubsection{Support of a business incubator (F7)}

The support of a business incubator increases the likelihood of success of companies with reproducible and scalable models (Murray, 2019). Considering that startups have a reproducible and scalable business model, we conclude that:

Hypothesis H7.0 The support of a business incubator improves the success of TBSs.

\subsubsection{Innovation and entrepreneurship ecosystem (F8)}

The innovation and entrepreneurship ecosystem generates the financial conditions necessary for business growth and development and is critical for the success of TBSs (Corrales-Estrada, 2019). Therefore, the better the ecosystem, the higher the probability of forming successful ventures. Based on this argument, we can affirm that:

Hypothesis H8.0 The innovation and entrepreneurship ecosystem increases the success of TBSs.

\subsubsection{Dynamic capability (F9)}

TBSs are flexible and adaptable to changes and, therefore, are susceptible to risky situations (Sulayman et al., 2014) that impact business success. Dynamic capability, i.e., reacting quickly and effectively to different situations, mitigates these risks. Therefore, we conclude that:

Hypothesis H9.0 Dynamic capability improves the success of TBSs.

\subsubsection{Innovative and entrepreneurial culture (F10)}

TBSs generate disruptive ideas and foster a culture of innovation, and all team members develop and adopt creative behaviours. Fini et al. (2009) have shown that resourceful organisations do not achieve success without having an innovative culture that allows for the development of new products and/or services. Therefore, given that startups are creative, we conclude that:

Hypothesis H10.0 Innovative and entrepreneurial culture increases the success of TBSs.

The 12 proposed hypotheses are shown in Table 4. Each prediction is shown as Hx.y, in which 'CSFx affects CSFy' and 'CSFx affects success S0'.

The effects of ten CSFs on TBSs success are shown in Figure 1. Factors F5-F10 directly affects entrepreneurial success, whereas factors F1-F4 indirectly affect success. 
Table 4 Hypothesis matrix: factor vs. factor and success

\begin{tabular}{|c|c|c|c|c|c|c|}
\hline \multirow{2}{*}{ Factors } & \multicolumn{5}{|c|}{ Factors } & \multirow{2}{*}{ Success } \\
\hline & $F 2$ & $F 3$ & $F 5$ & $F 9$ & $F 10$ & \\
\hline F1 & H1.2 & & & & & \\
\hline F2 & & $\mathrm{H} 2.3$ & & H2.9 & $\mathrm{H} 2.10$ & \\
\hline F3 & & & H3.5 & & & \\
\hline $\mathrm{F} 4$ & & & $\mathrm{H} 4.5$ & & & \\
\hline F5 & & & & & & $\mathrm{H} 5.0$ \\
\hline F6 & & & & & & H6.0 \\
\hline F7 & & & & & & H7.0 \\
\hline F8 & & & & & & H8.0 \\
\hline F9 & & & & & & H9.0 \\
\hline F10 & & & & & & H10.0 \\
\hline
\end{tabular}

\section{Methodology}

This section describes the process of data collection and analysis of results.

\subsection{Data collection}

A questionnaire was used for data collection. An online survey in Spanish was developed using Google Forms (Survey Google Form, 2018) based on the proposed model. The survey was applied to the CEOs of TBSs of six generations supported by non-reimbursable funds of the National Innovation Programme for Competitiveness and Productivity (Innóvate Perú, 2018) of the Ministry of Production of Peru from May 2018 to July 2019. The objective of the survey was to determine the perception CEOs have about CSFs for TBSs. In addition, the survey considered the effect of CSFs in each stage of business development, which is the subject of another study.

The survey contains five sections. Section 1 provides general data on TBS managers (eight questions). Section 2 describes the general characteristics of a TBS (seven questions). Section 3 assesses the opinions on business success (two questions). Section 4 evaluates the relationship between CSFs and the success at each stage of business development (eight questions). Section 5 examines the relationship between CSFs and the success of a TBS (one question). Only Sections 1, 2, and 5 were covered in this study. The questions in Section 5 were evaluated using a five-point Likert scale to assess the degree of influence, as follows:

1 none

2 low

3 intermediate

4 high

5 very high. 
After preparing the survey, a pilot test was conducted to validate the questions. The pilot test was carried out by 15 CEOs who verified whether the items were adequately related to the hypotheses. The wording of the questions was corrected to guarantee the use of appropriate language.

People were invited to participate in the Innóvate Perú survey by letter or e-mail. In addition, the survey was completed in-person by entrepreneurs from several TBSs during different business events in Lima, which were organised by several business incubators supported by Innóvate Peru. In total, 130 responses were obtained. Of these, five were discarded because of incomplete or inconsistent responses.

\subsection{Results analysis}

The following statistical analyses were performed:

1 data reliability (reliability and internal consistency using Cronbach's alpha)

2 descriptive analysis of the study population (demographics; mean, variance, mode, and distribution of responses)

3 SCA (a measurement of the relationship between a CSF and success of a TBS)

4 validation of results using student's t-test to verify the hypotheses.

\section{Results}

\subsection{Data reliability}

Cronbach's alpha was used to estimate data reliability. The validity of an instrument is the degree to which it measures what it was proposed to measure. The closer the alpha is to 1 , the higher the internal consistency of the data. The validity of the instrument is acceptable if the alpha is higher than 0.70 (Streiner, 2003). Cronbach's alpha was equal to 0.91 using R software, confirming data reliability (Figure 2).

Figure 2 Reliability of survey data using R software

\begin{tabular}{|rrrrrrrrr|r|}
\hline \multicolumn{2}{l}{ Reliability analysis } & & & & & & & \\
raw_alpha std.alpha & $G 6(\mathrm{smc})$ & average_r & $5 / \mathrm{N}$ & ase mean & sd median_r \\
0.91 & 0.9 & 1 & 0.051 & 9.3 & 0.0098 & 3.6 & 0.15 & 0.021 \\
\hline
\end{tabular}

\subsection{Descriptive analysis of the study population}

Of the 125 TBSs, $79 \%$ of companies were run by men, $38 \%$ of participants were aged 25 to 34 years, $94 \%$ of participants had previously owned a business, and $48 \%$ of entrepreneurs had completed postgraduate studies. Most TBSs (56\%) had four workers, and $84 \%$ operated in the city of Lima. The classification of the responses according to the business sector and financial support (seed capital or venture capital) is shown in Table 5. A total of $53 \%$ of startups worked in the area of education (Edtech, entrepreneurship that uses technology to improve teaching and learning) and health (Healthtech, a company 
that resolves health challenges), and $94 \%$ of the respondents were supported with either seed capital or venture capital.

Table 5 Classification of respondents

\begin{tabular}{|c|c|c|c|c|}
\hline Sector & $\begin{array}{l}\text { Financial support with seed } \\
\text { capital or venture capital) }\end{array}$ & Frequency & $(N=125)$ & Percentage \\
\hline \multirow[t]{2}{*}{ Edtech } & Yes & 38 & 41 & $33 \%$ \\
\hline & No & 3 & & \\
\hline \multirow[t]{2}{*}{ Fintech } & Yes & 18 & 19 & $15 \%$ \\
\hline & No & 1 & & \\
\hline \multirow[t]{2}{*}{ Foodtech } & Yes & 13 & 15 & $12 \%$ \\
\hline & No & 2 & & \\
\hline \multirow[t]{2}{*}{ Healthtech } & Yes & 24 & 25 & $20 \%$ \\
\hline & No & 1 & & \\
\hline \multirow[t]{2}{*}{ Insurtech } & Yes & 5 & 5 & $4 \%$ \\
\hline & No & 0 & & \\
\hline \multirow[t]{2}{*}{ Legaltech } & Yes & 6 & 6 & $5 \%$ \\
\hline & No & 0 & & \\
\hline \multirow[t]{2}{*}{ Retailtech } & Yes & 13 & 14 & $11 \%$ \\
\hline & No & 1 & & \\
\hline
\end{tabular}

The mean, variance, and mode of the responses on the perception of CSFs for TBSs are shown in Table A2. The average perception was greater than 3.7, indicating that the effect of CSFs was high.

For the descriptive analysis of the population, boxplots were used for data distribution. The boxplot shows the opinions entrepreneurs have on the relationships between CSFs. The median scores of the relationships F1 $\rightarrow$ F2, F2 $\rightarrow$ F9, F2 $\rightarrow$ F3, F3 $\rightarrow$ F5 and F4 $\rightarrow$ F5 were 5, indicating that the effect was very high [Figure 3(a)]. However, the median score of the relationship F2 $\rightarrow$ F10 was 3, indicating that the effect was intermediate. Black lines represent values close to a level of influence. Therefore, the boxplot is flat. White dots correspond to outliers.

The boxplot in Figure 3(b) shows entrepreneurs' opinions on the effect of each CSF on success of a TBS. The median scores for F5, F7, F8, and F10 were 5, indicating a very strong impact. However, the median values for F6 and F9 were 4, demonstrating a strong influence.

\section{$5.3 S C A$}

The objective of SCA is to determine the degree to which each CSF influences entrepreneurial success. The eigenvalues for SCA between each factor and success, as well as the variance and percentage of the variance of each component, are shown in Table 6 . The first two components could explain approximately $97 \%$ of the data $(82.4 \%$ $+14.5 \%$ ). Therefore, components 1 and 2 (C1 and $\mathrm{C} 2$ ) were used to build a contingency table (Table 7). 
Figure 3 Boxplot of the relationship between CSFs and the success of TBSs, (a) F1 $\rightarrow$ F2, $\mathrm{F} 2 \rightarrow \mathrm{F} 10, \mathrm{~F} 2 \rightarrow \mathrm{F} 9, \mathrm{~F} 2 \rightarrow \mathrm{F} 3, \mathrm{~F} 3 \rightarrow \mathrm{F} 5, \mathrm{~F} 4 \rightarrow \mathrm{F} 5$ (b) F5, F6, F7, F8, F9 and $\mathrm{F} 10 \rightarrow$ success (see online version for colours)

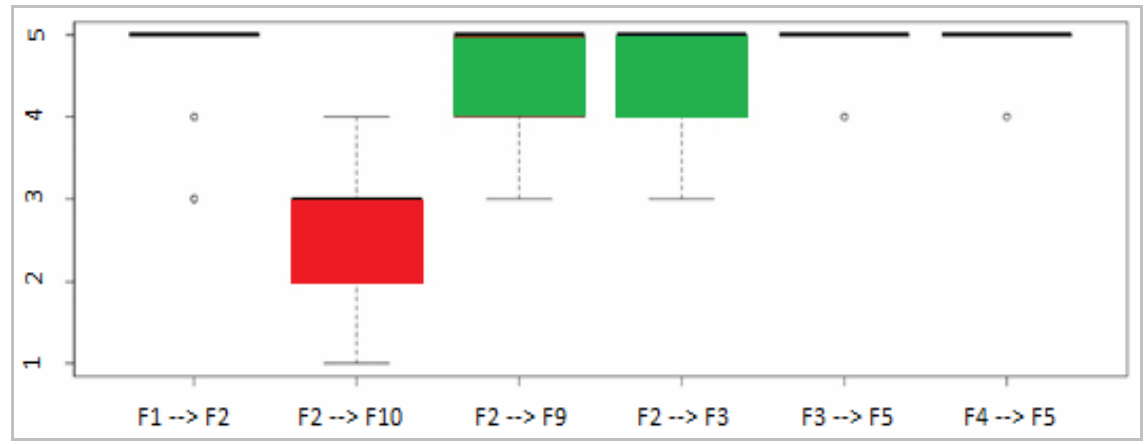

(a)

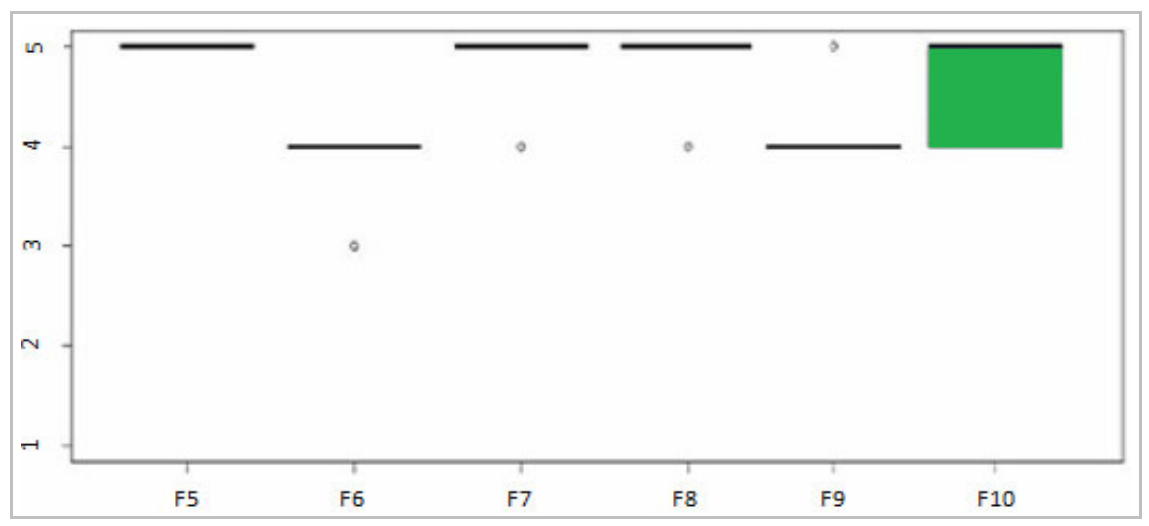

(b)

Table 6 Eigenvalues of analysis of the CFSs that contribute to the success of TBS

\begin{tabular}{lccccc}
\hline Component & 1 & 2 & 3 & 4 & 5 \\
\hline Value & 0.088721 & 0.015659 & 0.003174 & 0.000152 & $1 \mathrm{e}-06000$ \\
Percentage (\%) & 82.4 & 14.5 & 2.9 & 0.1 & 0.0 \\
\hline
\end{tabular}

Table 7 Contingency table of the CSFs that contribute to the success of TBS

\begin{tabular}{lcccccc}
\hline Factors & $F 5$ & $F 6$ & $F 7$ & $F 8$ & $F 9$ & $F 10$ \\
\hline Mass & 0.105756 & 0.007140 & 0.331102 & 0.002231 & 0.243641 & 0.310129 \\
ChiDist & 0.653062 & 0.525904 & 0.187348 & 0.837097 & 0.343751 & 0.245247 \\
Inertia & 0.045104 & 0.001975 & 0.011621 & 0.001563 & 0.028790 & 0.018653 \\
Dim. 1 & -2.014208 & -0.928072 & 0.619762 & 0.786974 & -0.978128 & 0.809318 \\
Dim. 2 & -2.055927 & -0.891296 & -0.156543 & -0.985416 & 1.457746 & -0.249399 \\
\hline
\end{tabular}

A contingency table was created to graphically represent the effect of CSFs on success (Table 7) and shows the degree of contribution of each factor to $\mathrm{C} 1$ and $\mathrm{C} 2$, the relationship between each factor and $\mathrm{C} 1$ and $\mathrm{C} 2$, the total frequency of each data point 
(mass), the value of the chi-square distribution (ChiDist), and the contingency value (inertia).

In the plot graph (Figure 4), the scores of the factors that affected success (value $=1$ ) were $\geq 4$, whereas the scores of the factors that exerted no effect (value $=0$ ) were $<4$. The graph shows which factors (blue points) are related to success (red triangle), i.e., the closer two data points are to each other, the closer their relationship is to each other, and the stronger is their influence.

Figure 4 SCA of the CSFs that contribute to the success of TBSs (see online version for colours)

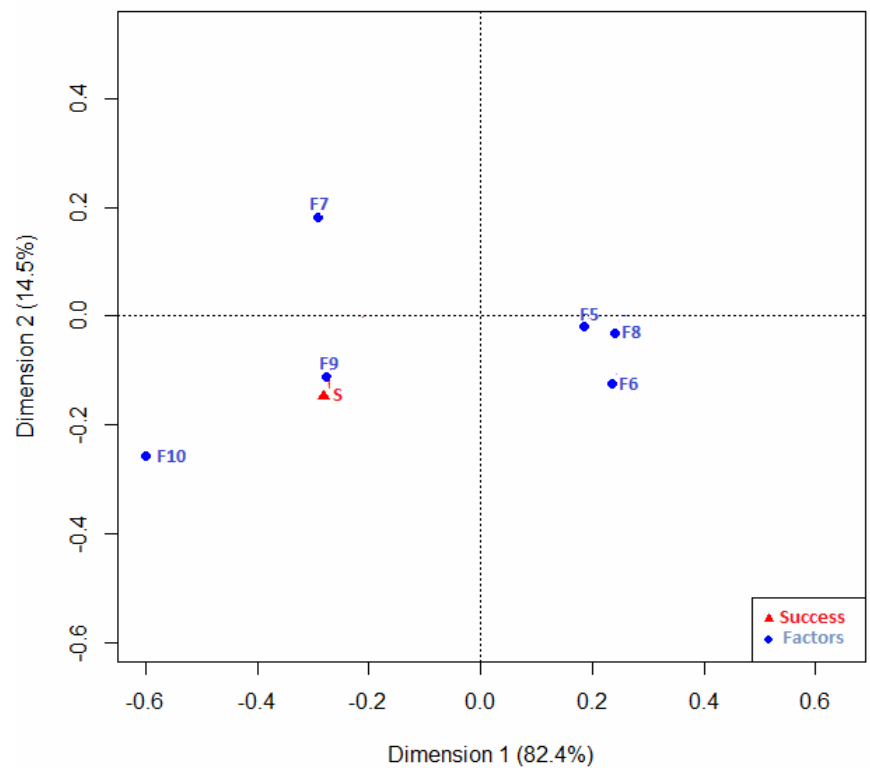

With respect to the effect of different CSFs, the results showed that:

a F5, F6, and F8 had a weak impact

b $\quad$ F7 exerted a moderate effect

c $\quad$ F9 and F10 had a strong influence.

\subsection{Student's t-test}

In this section, the student's t-test (McMullen, 1939) was applied to verify the hypotheses proposed in Section 3 . The null hypothesis $\left(H_{0}\right)$ and the alternative hypothesis $\left(H_{a}\right)$ were formulated so that $H_{a}$ mathematically stated what we wanted to demonstrate, and $H_{0}$ stated the opposite; $H_{a}$ was accepted if $H_{0}$ was rejected and vice versa. $H_{0}$ and $H_{a}$ were defined according to the following decision rules:

- $H_{0}=\mu<3.7$ (entrepreneurs believe that the average level of influence of a factor on the success of a TBS was lower than 3.7).

- $H_{a}=\mu>3.7$ (entrepreneurs believe that the average level of influence of a factor on the success of a TBS was higher than 3.7). 
Student's t value and the degrees of freedom were calculated at a $95 \%$ confidence level. To accept or reject $H_{0}$, the probability of error (p-value) was calculated using the equation proposed by Monroy and Rivera (2012) [equation (1)]. The level of significance ( $\alpha$ ) was $5 \%$. If the p-value was greater than $\alpha, H_{0}$ was accepted and $H_{a}$ was rejected. If the p-value was less than the level of significance $(\alpha), H_{0}$ was rejected and $H_{a}$ was accepted.

$$
t=(\bar{X}-u) /(s / \sqrt{n})
$$

where $\bar{X}$ is the mean, $\mu$ is the mean specified in the null hypothesis, $s$ is the standard deviation, $n$ and is the sample size.

The t-test results of the correlation between six CSFs and the relationship between these factors and the success of TBS according to equation (1) are shown in Table 8 . The correlations, t values, degrees of freedom (df), p-value, confidence interval, and estimated minimum and maximum mean values are shown in Table 8.

Table 8 Results of the student's t-test

\begin{tabular}{|c|c|c|c|c|c|c|c|}
\hline \multirow{2}{*}{ Hypothesis } & \multirow{2}{*}{$t$} & \multirow{2}{*}{$d f$} & \multirow{2}{*}{ p-value } & \multirow{2}{*}{$\frac{\text { Confidence }}{(\%)}$} & \multicolumn{2}{|c|}{ Estimated mean } & \multirow{2}{*}{ Result } \\
\hline & & & & & $\operatorname{Min}$ & $\operatorname{Max}$ & \\
\hline $\mathrm{H} 1.2$ & 30.20 & 125 & $5,13 \mathrm{E}-62$ & 95 & 4.8373 & 4.9548 & Support \\
\hline $\mathrm{H} 2.3$ & 11.35 & 125 & $6.84 \mathrm{E}-22$ & 95 & 4.4887 & 4.6953 & Support \\
\hline H2.9 & 16.28 & 125 & $6.13 \mathrm{E}-34$ & 95 & 4.6255 & 4.7985 & Support \\
\hline $\mathrm{H} 2.10$ & -19.49 & 125 & 0.095 & 95 & 2.4578 & 2.7422 & No support \\
\hline H3.5 & 24.78 & 125 & $1.03 \mathrm{E}-50$ & 95 & 4.7655 & 4.8985 & Support \\
\hline $\mathrm{H} 4.5$ & 26.30 & 125 & $7.59 \mathrm{E}-57$ & 95 & 4.7842 & 4.9118 & Support \\
\hline H5.0 & 6.475 & 125 & $2.53 \mathrm{E}-10$ & 95 & 4.9787 & 4.9906 & Support \\
\hline H6.0 & 13.58 & 125 & $7.65 \mathrm{E}-26$ & 95 & 3.8516 & 3.9564 & Support \\
\hline $\mathrm{H} 7.0$ & 49.59 & 125 & $3.99 \mathrm{E}-63$ & 95 & 4.9140 & 4.9899 & Support \\
\hline H8.0 & 61.25 & 125 & $1.71 \mathrm{E}-65$ & 95 & 4.9367 & 4.9993 & Support \\
\hline H9.0 & 1.746 & 125 & $9.63 \mathrm{E}-05$ & 95 & 3.9967 & 4.0512 & Support \\
\hline H10.0 & 18.59 & 125 & $5.72 \mathrm{E}-41$ & 95 & 4.6576 & 4.8144 & Support \\
\hline
\end{tabular}

The p-value was less than 0.05 for most hypotheses (H1.2, H2.3, H2.9, H3.5, H4.5, H5.0, H6.0, H7.0, H8.0, H9.0, H10.0), indicating that $H_{a}$ was accepted. Therefore, we can affirm with $95 \%$ confidence that the average score was $\geq 3.7$, demonstrating that the identified CSFs had a strong influence on entrepreneurial success (Table 8).

Hypothesis H2.10 was not supported $(\mathrm{p}>0.05)$ at a 95\% confidence level, indicating that knowledge absorptive capacity (F2) had a weak impact on the innovative and entrepreneurial culture (F10).

\section{Discussion and future research}

The results of the descriptive analysis of the study population showed that there was a high or very high influence between each CSFs and the success of TBSs, The median scores for F5, F7, F8, and F10 were 5, indicating a very strong impact (very high influence). However, the median values for F6 and F9 were 4, demonstrating a strong 
influence (high influence), i.e., indirect effects. For instance, technological surveillance (F1) indirectly impacted business success through knowledge absorptive capacity (F2) [Figure 3(a)], and user satisfaction (F5) directly affected success [Figure 3(b)].

Furthermore, the SCA results showed that all identified CSFs had a high to very high effect on success when considering approximately $97 \%$ of the data.

The results of student's t-test (Table 8) confirmed that 11 of the 12 hypotheses were valid because they were empirically tested and theoretically supported, whereas hypothesis H2.10 - knowledge absorptive capacity (F2) innovative and entrepreneurial culture (F10) - was rejected because the hypothesis test considered a strong effect to have an average score greater than $\mu=3.7$. The resulting weak effect could be explained by the characteristics of TBSs in Peru, in which most of the surveyed TBSs focused on know-how and innovation but not on research since these businesses do not have a research culture, in contrast to spin-offs.

The final conceptual model contained ten factors and 11 relationships and, therefore, constituted a robust model because of its theoretical foundation (Figure 5).

Figure 5 Final conceptual model

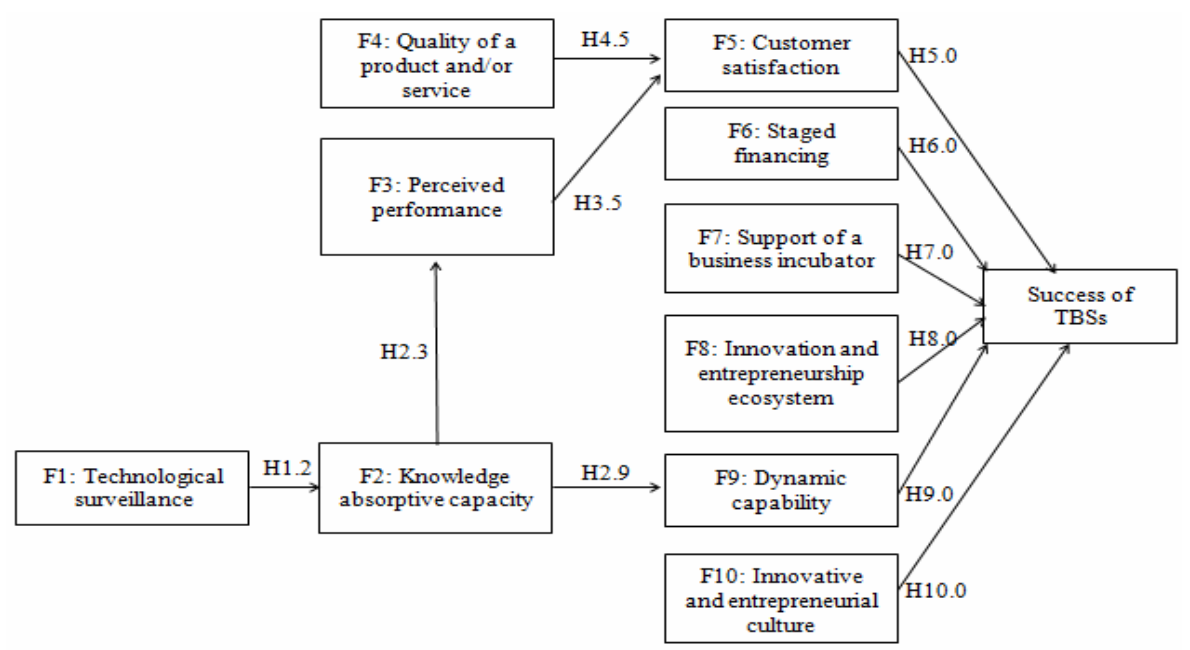

\subsection{Future studies}

Factors F5-F10 should be analysed at each stage of development of a TBS (seed, early, growth, expansion, and exit) to identify the factors that promote growth, strategic business development and starge success, and mitigate the risk of failure.

\section{Conclusions}

The ten CSFs for TBSs are technological surveillance (F1), knowledge absorptive capacity (F2), perceived performance (F3), the quality of a product and/or service (F4), customer satisfaction (F5), staged financing (F6), the support of a business incubator (F7), innovation and entrepreneurship ecosystem (F8), dynamic capability (F9), and 
innovative and entrepreneurial culture (F10). These factors were supported by several theories, including knowledge absorptive capacity, expectation confirmation, dynamic capability, and the success model of information systems. F5-F10 directly influenced business success, whereas F1-F4 indirectly influenced success.

An interpretation of the results leads to the following conclusion:

- Several studies identified CSFs for TBSs. However, there is no consensus on the definition of startup success. Therefore, success has been interpreted as increased sales, customer satisfaction, satisfying the demands of customers and organisations, having profits higher than the industry average, being purchased by another company for a price.

- The results of SCA of 125 TBSs in Peru showed that all relationships, except for $\mathrm{H} 2.10$, had either a high or very high effect on entrepreneurial success.

- Student's t-test results confirmed that 11 out of the 12 hypotheses were valid with a $95 \%$ confidence level. The final conceptual model contained ten factors and 11 relationships.

\section{Acknowledgements}

The authors are grateful Universidad Nacional Mayor de San Marcos (UNMSM), for the partial funding of this research, and the journal referees whose input added value to this article.

\section{References}

Abou-Moghli, A. and Al-Kasasbeh, M. (2012) 'Social network and the success of business startup', International Journal of Business and Management, Vol. 7, No. 9, pp.134-140.

Al-Fraihat, D., Joy, M. and Sinclair, J. (2020) 'Evaluating e-learning systems success: an empirical study', Computers in Human Behavior, January, Vol. 102, pp.67-86.

Almakenzi, S., Bramantoro, A. and Rashideh, W. (2015) 'A survivability model for Saudi ICT startups', International Journal of Computer Science and Information Technology, Vol. 7, No. 2, pp.145-157.

Anh, D., Hoa, Q. and Quoc, T. (2012) 'Critical success factors for Vietnamese software companies: a framework for investigation', Journal of Sociological Research, Vol. 3, No. 2, pp.160-169.

Ardito, L., Messeni Petruzelli, A. and Albino, V. (2015) 'From technological inventions to new products: a systematic review and research agenda of the main enabling factors', European Management Review, Vol. 12, No. 3, pp.113-147.

Arefin, M.S., Alam, M.S., Islam, M.R. and Rahaman, M. (2019) 'High-performance work systems and job engagement: the mediating role of psychological empowerment', Cogent Business and Management, Vol. 6, No. 1, DOI: 10.1080/23311975.2019.1664204.

Arora, S.K., Li, Y., Youtie, J. and Shapira, P. (2019) 'Measuring dynamic capabilities in new ventures: exploring strategic change in US green goods manufacturing using website data', The Journal of Technology Transfer, pp.1-30 [online] https://doi.org/10.1007/s10961-01909751-y.

Arruda, C., Silva, V. and Costa, V. (2013) 'The Brazilian entrepreneurial ecosystem of startups: an analysis of entrepreneurship determinants in Brazil as seen from the OECD pillars', Journal of Entrepreneurship and Innovation Management, Vol. 2, No. 3, pp.17-57. 
Balboni, B., Bortoluzzi, G., Tivan, M., Tracogna, A. and Venier, F. (2014) 'The growth drivers of startup firms and business modelling: a first step toward a desirable convergence', Management, Vol. 9, No. 2, pp.131-154.

Banda, J. and Lussier, R. (2015) 'Success factors for small businesses in Guanajuato, Mexico', International Journal of Business and Social Science, Vol. 6, No. 11, pp.1-17.

Baum, J.A.C. and Silverman, B.S. (2004) 'Picking winners or building them? Alliance, intellectual, and human capital as selection criteria in venture financing and performance of biotechnology startups', Journal of Business Venturing, Vol. 19, No. 3, pp.411-436.

Bertoni, F., Colombo, M. and Grilli, L. (2011) 'Venture capital financing and the growth of high-tech startups: disentangling treatment from selection effects', Research Policy, Vol. 40, pp.1028-1043.

Blank, S. and Dorf, B. (2012) The Startup Owner's Manual, The Step-by-Step Guide for Building a Great Company, KandS Ranch Press, Pescadero, CA.

Bocken, N. (2015) 'Sustainable venture capital - catalyst for sustainable startup success?', Journal of Cleaner Production, Vol. 108, Part A, pp.647-658.

Cabrera, E.M. and Mauricio, D. (2017) 'Factors affecting the success of women's entrepreneurship: a review of literature', International Journal of Gender and Entrepreneurship, Vol. 9, No. 1, pp.31-65.

CAF (2015) Annual Report 2014 (report), CAF, Bogotá [online] http://scioteca.caf.com/handle/ 123456789/759 (accessed 1 December 2017).

Cannone, G. and Ughetto, E. (2014) 'Born globals: a cross-country survey on high-tech startups', International Business Review, Vol. 23, No. 1, pp.272-283.

Chaston, I. and Scott, G.J. (2012) 'Entrepreneurship and open innovation in an emerging economy', Management Decision, Vol. 50, No. 7, pp.1161-1177.

Chen, Y.F., Tsai, C.W. and Liu, H.J. (2019) Applying the AHP model to explore key success factors for high-tech startups entering international markets', International Journal of E-Adoption (IJEA), Vol. 11, No. 1, pp.45-63.

Chirjevskis, A. and Dvortsova, A. (2012) 'Assessment of qualitative success factors of innovative e-business startups’, Social Science Letters, Vol. 2, No. 2, pp.51-56.

Chorev, S. and Anderson, A. (2006) 'Success in Israeli high-tech startups; critical factors and process', Technovation, Vol. 26, No. 2, pp.162-174.

Colombo, M. and Grilli, L. (2005) 'Founders' human capital and the growth of new technology-based firms: a competence-based view', Research Policy, Vol. 34, No. 6, pp.795-816.

Colombo, M. and Grilli, L. (2010) 'On growth drivers of high-tech startups: exploring the role of founders' human capital and venture capital', Journal of Business Venturing, Vol. 25, No. 6, pp.610-626.

Colombo, M., Delmastro, M. and Grilli, L. (2004) 'Entrepreneurs' human capital and the startup size of new technology-based firms', International Journal of Industrial Organization, Vol. 22, Nos. 8-9, pp.1183-1211.

Corrales-Estrada, M. (2019) Innovation and Entrepreneurship: A New Mindset for Emerging Markets, pp.267-278, Emerald Publishing Limited [online] https://doi.org/10.1108/978-178973-701-120191001.

Dana. L.P. (1988) 'More small business is not the answer for Peru', Journal of Small Business Management, July, Vol. 26, No. 3, pp.68-70.

Dana. L-P. and Mallet, J. (2014) 'An unusual empirical pattern in an indigenous setting: cooperative entrepreneurship among Brazil nut (Bertholletia excelsa) harvesters', Int. J. Entrepreneurship and Small Business, Vol. 22, No. 2, pp.137-158.

Davidsson, P., Lindmark, L. and Olofsson, C. (1994) 'New firm formation and regional development in Sweden', Reg. Stud., Vol. 28, No. 4, pp.395-410. 
Dornberger, U. and Zeng, X. (2009) 'The locational factors and performance of the high-tech startups in China', International Journal Entrepreneurship and Small Business, Vol. 7, No. 3, pp.312-323.

Ejermo, O. and Xiao, J. (2014) 'Entrepreneurship and survival over the business cycle: how do new technology-based firms differ?', Small Business Economics, Vol. 43, No. 2, pp.411-426.

Festel, G., Wuermseher, M. and Cattaneo, G. (2013) 'Valuation of early stage high-tech startup companies', International Journal of Business, Vol. 18, No. 3, pp.216-231.

Fini, R., Grimaldi, R. and Sobrero, M. (2009) 'Factors fostering academics to start up new ventures: an assessment of Italian founders' incentives', J. Technol. Transf., Vol. 34, No. 4, pp.380-402.

Friar, J. and Meyer, M. (2003) 'Entrepreneurship and startups in the Boston region: factors differentiating high-growth ventures from micro-ventures', Small Business Economics, Vol. 21, No. 2, pp.145-152.

Ganotakis, P. (2012) 'Founders' human capital and the performance of UK new technology based firms', Small Business Economics, Vol. 39, No. 2, pp.495-515.

Garcia-Muiña, F. and Navas-López, J. (2007) 'Explaining and measuring success in new business: the effect of technological capabilities on firm results', Technovation, Vol. 27, Nos. 1-2, pp.30-46.

Gartner, W. and Liao, J. (2012) 'The effects of perceptions of risk, environmental uncertainty and growth aspirations on new venture creation success', Small Business Economics, Vol. 39, No. 3, pp.703-712.

Gimmon, E. and Levie, J. (2010) 'Founder's human capital, external investment, and the survival of new high-technology ventures', Research Policy, Vol. 39, No. 9, pp.1214-1226.

Greve, A. and Salaff, J.W. (2003) 'Social networks and entrepreneurship', Entrepreneurship Theory and Practice, Vol. 28, No. 1, pp.1-20.

Grilli, L. and Murtinu, S. (2014) 'Government, venture capital and the growth of European high-tech entrepreneurial firms', Research Policy, Vol. 43, No. 9, pp.1523-1543.

Groenewegen, G. and De Langen, F. (2012) 'Critical success factors of the survival of start-ups with a radical innovation', Journal of Applied Economics and Business Research, Vol. 2, No. 3, pp.155-171.

Hale, K. (2019) 'How to evaluated startup idea?', Y Combinator [online] 25 July 2019. https://www.ycombinator.com/library/6e-how-to-evaluate-startup-ideas (accessed 5 September 2019).

Haltiwanger, J., Jarmin, R. and Miranda, J. (2012) Who Creates Obs? Small vs. Large vs. Young?, unpublished working paper, University of Maryland and US Census Bureau.

Honorine, A.N.D. and Emmanuelle, D. (2019) 'Stage financing and syndication in the IPO underpricing of venture-backed firms: venture capital and IPO underpricing', The International Journal of Entrepreneurship and Innovation, Vol. 20, No. 4, pp.289-300.

Hormiga, E., Batista-Canino, R. and Sánchez-Medina, A, (2010) 'The role of intellectual capital in the success of new ventures', International Entrepreneurial Management Journal, Vol. 7, No. 1, pp.71-92.

Hormiga, E., Batista-Canino, R. and Sánchez-Medina, A. (2011) 'The impact of relational capital on the success of new business startups', Journal of Small Business Management, Vol. 49, No. 4, pp.617-638.

Hyder, S. and Lussier, R. (2016) 'Why businesses succeed or fail: A study on small businesses in Pakistan', Journal of Entrepreneurship in Emerging Economics, Vol. 8, No. 1, pp.82-100.

Innóvate Perú (2018) National Innovation Program for Competitiveness and Productivity of Perú, Innóvate Perú [online] https://www.innovateperu.gob.pe/ (accessed 10 Julio 2018).

Joshi, K. and Satyanarayana, K. (2014) ' What ecosystem factors impact the growth of high-tech start-ups India?', Asian Journal of Innovation and Policy, Vol. 3, No. 2, pp.216-244 
Kakati, M. (2003) 'Success criteria in high-tech new ventures', Technovation, Vol. 23, No. 5, pp.447-457.

Kim, B., Kim, H. and Jeon, Y. (2018) 'Critical success factors of a design startup business', Sustainability, Vol. 10, No. 9, p.2981, DOI: 10.3390/su10092981.

Kim, Y. and Heshmati, A. (2010) 'Analysis of Korean IT startups' initial public offering and their post-IPO performance', Journal of Productivity Analysis, Vol. 34, No. 2, pp.133-149.

Ko, C.R. and An, J.I. (2019) 'Success factors of student startups in Korea: from employment measures to market success', Asian Journal of Innovation and Policy, Vol. 8, No. 1, pp.097-121.

Konsek-Ciechonska, J. (2019) 'Startup companies challenges in Poland', Knowledge International Journal, Vol. 30, No. 6, pp.1621-1626.

Krejci, M., Strielkowski, W. and Cabelkova, I. (2015) 'Factors that influence the success of small and medium enterprises in ICT: a case study from the Czech Republic', Business: Theory and Practice, Vol. 16, No. 2, pp.304-315.

Lasch, F., Le Roy, F. and Yami, S. (2007) 'Critical growth factors of ICT startups', Management Decision, Vol. 45, No. 1, pp.62-75.

Luna-Perejon, F., Malwade, S., Styliadis, C., Civit, J., Cascado-Caballero, D., Konstantinidis, E. and Li, Y.C. (2019) 'Evaluation of user satisfaction and usability of a mobile app for smoking cessation', Computer Methods and Programs in Biomedicine, DOI: 105042.

Maine, E., Shapiro, D. and Vining, A. (2010) 'The role of clustering in the growth of new technology-based firms', Small Business Economics, Vol. 34, No. 2, pp.127-146.

McAdam, M. and McAdam, R. (2008) 'High tech startups in university science park incubators: the relationship between the startup's lifecycle progression and use of the incubator's resources', Technovation, Vol. 28, No. 5, pp.277-290.

McMullen, L. (1939) 'William sealy gosset, 1876-1937: (1) 'Student as a man', Biometrika, Vol. 30, Nos. 3-4, pp.205-210.

Monroy, L.G.D. and Rivera, M.A.M. (2012) Estadística multivariada: Inferencia y métodos, Editorial Universidad Nacional de Colombia, Bogota, Columbia.

Morteza, S., Pitts, B., Ehsani, M. and Kordnaeij, A. (2013) 'The vital factors for small and medium sized sport enterprises startups', Asian Social Science, Vol. 9, No. 5, pp.243-253.

Mueller, S., Volery, T. and Von, B. (2012) 'What do entrepreneurs actually do? An observational study of entrepreneurs' everyday behavior in the start-up and growth stages', Entrepreneurship Theory and Practice, Vol. 36, No. 5, pp.995-1017.

Murray, A. (2019) 'Supporting academic entrepreneurship: a blueprint for a university based business incubator', Journal of Higher Education Service Science and Management, Vol. 2, No. 2, pp.1-9.

Nishimura, J.S. and Tristán, O.M. (2011) 'Using the theory of planned behavior to predict nascent entrepreneurship', Academia. Revista Latinoamericana de Administración, Vol. 46, pp.55-71.

Oakey, R. (2003) 'Technical entrepreneurship in high technology small firms: some observations on the implications for management', Technovation, Vol. 23, No. 8, pp.679-688.

OECD (2016) Start-Up Latina America: Building an Innovative Future Publishing, Paris [online] http://dx.doi.org/10.1787/9789264265141-es.

Petru, N., Pavlák, M. and Polák, J. (2019) 'Factors impacting startup sustainability in the Czech Republic', Innovative Marketing, Vol. 15, No. 3, pp.1-15, DOI: 10.21511/im.15(3). 2019.01.

Pirolo, L. and Presutti, M. (2010) 'The impact of social capital on the startups' performance growth', Journal of Small Business Management, Vol. 48, No. 2, pp.197-227.

Preisendorfer, P., Bitz, A. and Bezuidenhout, F. (2012) 'Business startups and their prospects of success in South African townships', South African Review of Sociology, Vol. 43, No. 3, pp.3-23. 
Prohorovs, A., Bistrova, J. and Ten, D. (2018) 'Startup success factors in the capital attraction stage: founders' perspective', Journal of East-West Business, DOI: 10.1080/10669868.2018. 1503211.

Pugliese, R., Bortoluzzi, G. and Zupic, I. (2016) 'Putting process on track: empirical research on start-ups' growth drivers', Management Decision, Vol. 54, No. 7, pp.1633-1648.

Reynolds, P. and Miller, B. (1992) 'New firm gestation: conception, birth, and implications for research', Journal of Business Venturing, Vol. 7, No. 5, pp.405-417.

Ries, E. (2011) The Lean Startup: How Today's Entrepreneurs Use Continuous Innovation to create Radically Successful Businesses, Crown Publishing Group, New York, NY, USA.

Roa, L.A.G., Martínez, H.H. and Ariza, H.M. (2018) 'Contextualization of ICT tools for technological surveillance systems associated with innovation processes', International Journal of Engineering and Technology (IJET), Vol. 10, No 6, DOI: 10.21817/ijet/2018/ v10i6/181006036.

Rojas, F. and Huergo, E. (2016) 'Characteristics of entrepreneurs and public support for NTBFs', Small Business Economics, Vol. 47, No. 2, pp.1-20.

Roy, S., Modak, N. and Dan, P.K. (2020) 'Managerial support to control entrepreneurial culture in integrating environmental impacts for sustainable new product development', Sustainable Waste Management: Policies and Case Studies, pp.637-646, Springer, Singapore.

Santisteban, J. and Mauricio, D. (2017) 'Systematic literature review of critical success factors of information technology startup', Academy of Entrepreneurship, Vol. 23, No. 2, pp.1528-2686.

Scarborough, N. and Zimmerer, T. (2003) Effective Small Business Management: An Entrepreneurial Approach, Prentice Hall Publishing, New Jersey.

Schneider, J., Dowling, M. and Raghuram, S. (2007) 'Empowerment as a success factor in startup companies', RMS, Vol. 1, No. 2, pp.167-184.

Sefiani, Y. and Bown, R. (2013) 'What influences the success of manufacturing SMEs? A perspective from tangier', International Journal of Business and Social Science, Vol. 4, No. 7, pp.297-309.

Senivongse, C., Bennet, A. and Mariano, S. (2019) 'Clarifying absorptive capacity and dynamic capabilities dilemma in high dynamic market IT SMEs', VINE Journal of Information and Knowledge Management Systems, Vol. 49, No. 3, pp.372-396 [online] https://oi.org/10.1108/ VJIKMS-11-2018-0105.

Serida, J., Guerrero, C., Alzamora, J., Borda, A. and Morales, O. (2017) Global Entrepreneurship Monitor: Perú 2016-2017, Universidad ESAN, Lima [online] https://repositorio.esan.edu.pe/ bitstream/handle/20.500.12640/1249/reporte-gem-2016-2017-final1511885927.pdf?sequence $=1$ \&isAllowed $=y$ (accessed 1 June 2018).

Song, M., Podoynitsyna, K., Van der Bij, H. and Halman, J. (2008) 'Success factors in new ventures: a meta-analysis', The Journal of Product Innovation Management, Vol. 25, No. 1, pp.7-27.

Spiegel, O., Abbassi, P., Zylka, P., Schlagwein, D., Fischbach, K. and Schoder, D. (2015) 'Business model development, founders' social capital and the success of early stage internet startups: a mixed-method study', Information Systems Journal, Vol. 26, No. 5, pp.421-449.

Spyros, J.V. and Nickolaos, G.T. (2012) 'Factors influencing entrepreneurial process and firm startups: evidence from central Greece', Journal Knowledge Economics, Vol. 3, No. 3, pp.250-264.

Strehle, F., Katzy, B. and Davila, T. (2010) 'Learning capabilities and the growth of technology-based new ventures', International Journal Technology Management, Vol. 52, Nos. $1 / 2$, pp.26-45.

Streiner, D. (2003) 'Starting at the beginning: an introduction to coefficient alpha and internal consistency', Journal of Personality Assessment, Vol. 80, No. 1, pp.99-103.

Sulayman, M., Mendes, E., Urquhart, C., Riaz, M. and Tempero, E. (2014) 'Towards a theoretical framework of SPI success factors for small and medium web companies', Information and Software Technology, Vol. 56, No. 7, pp.807-820. 
Survey Google Form (2018) [online] https://docs.google.com/forms/d/e/1FAIpQLSdkDDVaj4ito1 Gux0Z3vKYVOJEe_1By0vYPeSIP-wus4gjE9w/viewform (accessed 1 March 2018).

Thiranagama, R. and Edirisinghe, K. (2015) 'Factors affecting small business startup of engineers and accountants in Sri Lanka', NSBM Business and Management Journal, Vol. 6, No. 1, pp.84-107.

Timmons, J. and Spinelli, S. (2004) New Venture Creation: Entrepreneurship for the 21st Century, McGraw-Hill/Irwin, New York.

Van Gelderen, M., Thurik, R. and Bosma, N. (2005) 'Success and risk factors in the pre-startup phase', Small Business Economics, Vol. 24, No. 4, pp.365-380.

Wei-Wen, W. (2009) 'A competency-based model for the success of an entrepreneurial startup', WSEAS Transactions on Business and Economics, Vol. 6, No. 6, pp.279-291.

World Economic Forum (2018) The Future of Jobs Report 2018, Center for the New Economy and Society, WEF, Geneva [online] http://www3.weforum.org/docs/WEF_Future_of_ Jobs_2018.pdf (accessed 1 October 2019).

Yoo, C., Yang, D., Kim, H. and Heo, E. (2012) 'Key value drivers of startup companies in the new media industry - the case of online games in Korea', Journal of Media Economics, Vol. 25, No. 4, pp.244-260.

Yoon-Jun, L. (2010) 'Technology strategy by growth stage of technology-based venture companies', International Review of Business Research Papers, Vol. 6, No. 6, pp.216-234.

\section{Appendix}

Table A1 CFSs that influence the success of TBSs

\begin{tabular}{|c|c|c|c|}
\hline \multicolumn{2}{|c|}{ Factor } & \multirow[b]{2}{*}{$\begin{array}{l}\text { Definition } \\
\text { Company founders with industry } \\
\text { experience have a reliable and } \\
\text { extensive network of contacts that } \\
\text { facilitate entrepreneurial } \\
\text { development and growth. }\end{array}$} & \multirow{2}{*}{\begin{tabular}{l}
\multicolumn{1}{c}{ Source } \\
Thiranagama and Edirisinghe \\
(2015), Hyder and Lussier \\
(2016), Pugliese et al. (2016), \\
Rojas and Huergo (2016)
\end{tabular}} \\
\hline 1 & $\begin{array}{l}\text { Industry } \\
\text { experience }(+)\end{array}$ & & \\
\hline 2 & $\begin{array}{l}\text { Business } \\
\text { experience }(+)\end{array}$ & $\begin{array}{l}\text { The business experience of company } \\
\text { founders facilitates business } \\
\text { development and prevents } \\
\text { management errors. }\end{array}$ & $\begin{array}{l}\text { Gartner and Liao (2012), } \\
\text { Mueller et al. (2012), Bocken } \\
\text { (2015), Pugliese et al. (2016) }\end{array}$ \\
\hline 3 & $\begin{array}{l}\text { Academic } \\
\text { training }(+)\end{array}$ & $\begin{array}{l}\text { Academic training in management } \\
\text { courses by company founders } \\
\text { improves business growth. }\end{array}$ & $\begin{array}{l}\text { Hyder and Lussier (2016), } \\
\text { Pugliese et al. (2016), Rojas } \\
\text { and Huergo (2016) }\end{array}$ \\
\hline 4 & $\begin{array}{l}\text { Technological } \\
\text { and business } \\
\text { capabilities of } \\
\text { the team }(+)\end{array}$ & $\begin{array}{l}\text { Technical and managerial skills, } \\
\text { abilities, and knowledge necessary to } \\
\text { obtain a competitive advantage. }\end{array}$ & $\begin{array}{l}\text { Yoon-Jun }(2010) \text {, } \\
\text { Groenewegen and } \\
\text { De Langen }(2012)\end{array}$ \\
\hline 5 & $\begin{array}{l}\text { Experience in } \\
\text { research and } \\
\text { development }(+)\end{array}$ & $\begin{array}{l}\text { Previous experience in research } \\
\text { helps create innovative products. }\end{array}$ & Baum and Silverman (2004) \\
\hline 6 & $\begin{array}{l}\text { Experience in } \\
\text { management }(+)\end{array}$ & $\begin{array}{l}\text { The experience of entrepreneurs in } \\
\text { managing the resources necessary to } \\
\text { achieve success. It also describes the } \\
\text { competencies (attitudes, skills, or } \\
\text { abilities) required to meet objectives } \\
\text { and goals. }\end{array}$ & $\begin{array}{l}\text { Arruda et al. (2013), } \\
\text { Cannone and Ughetto (2014), } \\
\text { Thiranagama and Edirisinghe } \\
\text { (2015), Hyder and Lussier } \\
\text { (2016) }\end{array}$ \\
\hline
\end{tabular}

Source: Santisteban and Mauricio (2017) 
Table A1 CFSs that influence the success of TBSs (continued)

\begin{tabular}{|c|c|c|c|}
\hline \multicolumn{2}{|c|}{ Factor } & \multirow{2}{*}{$\begin{array}{l}\text { Definition } \\
\text { The characteristics and skills of an } \\
\text { entrepreneur to lead the organisation } \\
\text { to meet its objectives. }\end{array}$} & \multirow{2}{*}{\begin{tabular}{l}
\multicolumn{1}{c}{ Source } \\
Schneider et al. (2007), \\
Wei-Wen (2009)
\end{tabular}} \\
\hline 7 & $\begin{array}{l}\text { Entrepreneurial } \\
\text { leadership }(+)\end{array}$ & & \\
\hline 8 & $\begin{array}{l}\text { Gender of the } \\
\text { entrepreneur }(+)\end{array}$ & $\begin{array}{l}\text { The participation of men and women } \\
\text { as company founders. }\end{array}$ & Friar and Meyer (2003) \\
\hline 9 & $\begin{array}{l}\text { The age of the } \\
\text { entrepreneur }(+)\end{array}$ & $\begin{array}{l}\text { This factor is relevant for creating a } \\
\text { business, and the probability of } \\
\text { establishing a business decreases as } \\
\text { the entrepreneur's age increases. }\end{array}$ & Oakey (2003) \\
\hline 10 & $\begin{array}{l}\text { Motivation of the } \\
\text { entrepreneur }(+)\end{array}$ & $\begin{array}{l}\text { The company founder's motivation } \\
\text { represents his commitment to a } \\
\text { business project or plan }\end{array}$ & $\begin{array}{l}\text { Ganotakis (2012), Greve and } \\
\text { Salaff (2003) }\end{array}$ \\
\hline 11 & $\begin{array}{l}\text { Organisational } \\
\text { size }(+)\end{array}$ & $\begin{array}{l}\text { The number of employees. The } \\
\text { larger is the size of the } \\
\text { entrepreneurial team, the larger is the } \\
\text { talent pool. }\end{array}$ & $\begin{array}{l}\text { Joshi and Satyanarayana } \\
\text { (2014), Cannone and Ughetto } \\
\text { (2014), Thiranagama and } \\
\text { Edirisinghe (2015), Rojas and } \\
\text { Huergo (2016) }\end{array}$ \\
\hline 12 & $\begin{array}{l}\text { Organisational } \\
\text { age }(+)\end{array}$ & $\begin{array}{l}\text { Years of operation of the company } \\
\text { from its inception. }\end{array}$ & Haltiwanger et al. (2012) \\
\hline 13 & $\begin{array}{l}\text { Product } \\
\text { innovation }(+)\end{array}$ & $\begin{array}{l}\text { The rate at which innovative } \\
\text { products and/or services are } \\
\text { introduced into the market. }\end{array}$ & Ardito et al. (2015) \\
\hline 14 & Location $(+)$ & $\begin{array}{l}\text { The geographic location of a startup } \\
\text { and the regional proximity to } \\
\text { suppliers and customers facilitates } \\
\text { business growth. }\end{array}$ & Hormiga et al. (2011) \\
\hline 15 & Clustering (+) & $\begin{array}{l}\text { Group of interrelated companies that } \\
\text { work in the same industrial sector } \\
\text { and collaborate strategically to share } \\
\text { benefits. }\end{array}$ & $\begin{array}{l}\text { Maine et al. (2010), Yoon-Jun } \\
\text { (2010), Mueller et al. (2012) }\end{array}$ \\
\hline 16 & Partner (+) & $\begin{array}{l}\text { A person or company with which an } \\
\text { agreement or alliance is maintained. }\end{array}$ & Sefiani and Bown (2013) \\
\hline 17 & $\begin{array}{l}\text { Government } \\
\text { support }(+)\end{array}$ & $\begin{array}{l}\text { The financial support of government } \\
\text { through seed capital in the initial } \\
\text { stage of business development, and } \\
\text { support programs for TBSs. }\end{array}$ & $\begin{array}{l}\text { Lasch et al. (2007), Anh et al. } \\
\text { (2012), Arruda et al. (2013), } \\
\text { Pugliese et al. (2016) }\end{array}$ \\
\hline 18 & $\begin{array}{l}\text { Venture } \\
\text { capital }(+)\end{array}$ & $\begin{array}{l}\text { Entrepreneurial capital that supports } \\
\text { high-potential and high-risk TBSs in } \\
\text { the growth phase. }\end{array}$ & $\begin{array}{l}\text { Bertoni et al. (2011), Grilli } \\
\text { and Murtinu (2014), Bocken } \\
\text { (2015), Almakenzi et al. } \\
(2015)\end{array}$ \\
\hline 19 & $\begin{array}{l}\text { Level of } \\
\text { competition }(+)\end{array}$ & $\begin{array}{l}\text { The level of competition between } \\
\text { TBSs from the same industrial } \\
\text { sector. }\end{array}$ & $\begin{array}{l}\text { Song et al. (2008), } \\
\text { Arruda et al. (2013) }\end{array}$ \\
\hline 20 & $\begin{array}{l}\text { Regional } \\
\text { dynamism (-) }\end{array}$ & $\begin{array}{l}\text { The high rate of change in the local } \\
\text { environment. }\end{array}$ & Timmons and Spinelli (2004) \\
\hline 21 & $\begin{array}{l}\text { Science and } \\
\text { technology } \\
\text { policy }(+)\end{array}$ & $\begin{array}{l}\text { Laws established by political } \\
\text { authorities for the development of } \\
\text { science and technology. }\end{array}$ & $\begin{array}{l}\text { Scarborough and } \\
\text { Zimmerer (2003) }\end{array}$ \\
\hline
\end{tabular}


Table A2 Mean, variance and mode of the responses on CFSs that affect success of TBSs

\begin{tabular}{lccc}
\hline Hypothesis & Mean & Variance & Mode \\
\hline H1.2 & 4.90 & 0.33 & 5 \\
H2.3 & 4.59 & 0.58 & 5 \\
H2.9 & 4.71 & 0.49 & 5 \\
H2.10 & 2.60 & 0.80 & 3 \\
H3.5 & 4.83 & 0.38 & 5 \\
H4.5 & 4.85 & 0.36 & 5 \\
H5.0 & 0.14 & 5 \\
H6.0 & 0.30 & 4 \\
H7.0 & 3.90 & 0.21 & 5 \\
H8.0 & 4.95 & 0.18 & 5 \\
H9.0 & 4.97 & 0.15 & 3 \\
H10.0 & 4.02 & 0.44 & 4 \\
\hline
\end{tabular}

